\title{
PERAN BIMBINGAN KONSELING DALAM MENGATASI ANAK TEMPER TANTRUM
}

\author{
Adela Tsamrotul Fikriyah \\ Universitas Islam Negeri Sunan Ampel Surabaya \\ Email: fikriyahadela@gmail.com \\ Imam Syafi'i \\ Universitas Islam Negeri Sunan Ampel Surabaya \\ Email: imamsyafii.iwa@gmail.com
}

\begin{abstract}
Early childhood is a time to learn to deal with feelings, whether disappointed, sad, angry when what they want is not fulfilled. That's all a natural and natural feeling. Sometimes without us realizing it we as adults clog an emotion, for example distracting a child. However, if this feeling cannot be expressed by the child, there will be a pile of emotions that can later explode and get out of control, and appear like a tamper tantrum. Expressing emotions with dangerous actions is a form of tantrums so that children get what they want or need. The older the child, the more energy he puts into expressing his emotions. Therefore it is difficult for adults to control and prevent uncontrollable behavior. The purpose of this study was to determine the role of counseling guidance in overcoming children with temper tantrums in RA Anak Salih Suwayuwo, precisely in group A children. Researchers used qualitative methods in their research. Counseling guidance at RA Anak Salih Suwayuwo is carried out through various stages of certain services.
\end{abstract}

Key words: role of counseling guidance, tamper tantrum

\begin{abstract}
Abstrak: Masa anak usia dini merupakan masa untuk belajar menghadapi suatu perasaan. Seperti halnya rasa kecewa, sedih, marah saat apa yang mereka kehendaki tidak terpenuhi. Hal tersebut merupakan suatu rasa yang wajar dan natural. Tanpa kita sadari kita sebagai orang dewasa menyumbat suatu emosi tersebut, misalnya mengalihkan perhatian anak. Akan tetapi jika rasa ini tidak bisa diutarakan oleh anak akan terjadi suatu emosi yang yang nantinya dapat meledak dan tidak terkendali, dan muncullah seperti tamper tantrum. Mengekspresikan emosi dengan tindakan-tindakan yang berbahaya merupakan salah satu bentuk tantrum agar anak mendapatkan yang mereka inginkan atau butuhkan. Semakin besar anak maka semakin banyak pula tenaga yang ia lakukan untuk meluapkan emosinya. Maka dari itu sulit bagi orang dewasa untuk mengendalikan dan mencegah tingkahlakunya yang tidak terkendali. Tujuan diadakannya penelitian ini untuk mengetahui peran bimbingan konseling dalam mengatasi anak yang temper tantrum di RA Anak Shaleh Suwayuwo tepatnya pada anak kelompok A. Peneliti meggunakan metode kualitatif dalam penelitiannya. Bimbingan konseling di RA Anak Shaleh Suwayuwo dilakukan melalui berbagai tahap-tahap layanan tertentu.
\end{abstract}

Kata kunci: bimbingan konseling, tamper tantrum, anak usia dini 
Adela Tsamrotul Fikriyah, Imam Syafi'i, Peran Bimbingan Konseling Dalam Mengatasi Anak Temper Tantrum

\section{PENDAHULUAN}

Anak usia dini adalah bayi yang baru lahir sampai berusia kurang lebih enam tahun, dimana pada masa tersebut anak mengalami perkembangan dan pertumbuhan yang sangat pesat yang disebut sebagai masa keemasan. Dadan Suryana mengemukakan bahwa "anak usia dini merupakan suatu periode yang sangat penting, karena di dalam periode ini potensi anak berkembang sangat cepat dan tidak bisa diulang lagi pada masa selanjutnya". ${ }^{1}$ Setiap anak memiliki kemampuan dan keunikan yang berbeda-beda, dan kemampuan tersebut dapat tercapai karena adanya pengaruh dari lingkungan masing-masing.

Pendidikan adalah proses pengalaman dalam meningkatkan potensi dan keilmuan yang dimiliki oleh setiap individu dengan cara bertahap. Pendidikan menunjukkan suatu proses bimbingan, tuntunan atau pimpinan yang di dalamnya mengandung unsur-unsur seperti mendidik, peserta didik, tujuan dan sebagainya. Terdapat dua jenis pendidikan yaitu pendidikan formal dan non formal. Jika di dalam memfasilitasi perkembangan anak, maka melalui pendidikan formal maupun non formal anak bisa mandiri dan percaya diri sehingga tidak tergantung kepada orang lain.

PAUD (pendidikan anak usia dini) adalah jalur pendidikan formal untuk anak usia dini dan bertujuan untuk memberikan stimulasi sehingga anak akan lebih berpotensi. Pendidikan anak usia dini ini diselenggarakan dari anak sejak lahir hingga berumur 6 tahun, hal tersebut sesuai dengan Undang-undang no 20 tahun 2003 pasal 28 ayat 1 tentang sistem pendidikan. ${ }^{2}$ Mengasuh, membimbing dan memberikan pengajaran yang

\footnotetext{
1 Dadan Suryana, "Teori Dan Praktek Pembelajaaran," International Journal of Physiology 6, no. 1 (2018): 2018.

2 Indana Khoiroh, "Bimbingan Dan Konseling Islam Dengan Pendekatan Behaviour Dalam Menangani Tantrum Seorang Anak Di TPQ Al-Istiqomah Wedoro Candi Waru Sidoarjo" (2014).
} 
tepat yaitu upaya untuk menstimulasi agar anak mampu dan memiliki ketrampilan. Hal tersebut dapat di dukung dengan adanya pelaksanaan bimbingan dan konseling di dalam lembaga PAUD.

Secara bahasa bimbingan diartikan sebagai memberi jalan dan konseling diartikan sebagai berbicara bersama. Menurut Rogers 3 konseling dikatakan sebagai hubungan yang mendukung, dimana salah satu pihak bertujuan meningkatkan kemampuan pihak lain untuk dapat menghadapi permasalahan yang dihadapinya. Menurut Prayitno 4 bimbingan konseling memiliki tujuan untuk membantu individu menjadi manusia yang mandiri, memiliki kemampuan untuk memahami diri sendiri dan lingkungan secara positif dan dinamis, mampu mengambil keputusan yang telah diambil, serta menjalankan norma-norma yang berlaku dan pada akhirnya individu mampu mewujudkan diri sendiri secara optimal.

Rentang usia 4-6 tahun, anak dalam masa penyesuaian dirinya dengan lingkungan sekitar hingga mereka merasa bahwa dirinya termasuk salah satu bagian di lingkungan tersebut. Pada dasarnya kita sebagai pendidik haruslah lebih berhati-hati dalam memberikan contoh pada anak, karena disitulah anak akan melihat serta menirunya. Menurut Hurlock ${ }^{5}$ faktor lingkungan sangat berpengaruh dalam pembentukan perilaku anak usia dini. Maka dari itu, masa-masa tersebut dinamakan masa keemasan atau golden age.

Pepatah mengatakan "pendidikan pertama adalah keluarga". Dapat diartikan bahwa bukan berarti anak langsung diajarkan calistung (membaca, menulis dan berhitung) akan tetapi penanaman perilaku yang

${ }^{3}$ Susiana, "Pelaksanaan Bimbingan Dan Konseling Bagi Anak Jalanan Di Padepokan Anggur ljo Ngaliyan Semarang," Walisongo Repository (Universitas Islam Negeri Walisongo Semarang, 2019).

${ }^{4}$ H Kamaluddin, "Bimbingan Dan Konseling Sekolah," Jurnal Pendidikan Dan Kebudayaan 17, no. 4 (2011): 447, https://doi.org/10.24832/jpnk.v17i4.40.

${ }^{5}$ Joko Tri Suharsono, Aris Fitriyani, and Arif Setyo Upoyo, "Hubungan Pola Asuh Orang Tua Terhadap Kemampuan Sosialisasi Pada Anak Prasekolah Di TK Pertiwi Purwokerto Utara," Jurnal Keperawatan Soedirman 4, no. 3 (2009): 112-18. 
Adela Tsamrotul Fikriyah, Imam Syafi'i, Peran Bimbingan Konseling Dalam Mengatasi Anak Temper Tantrum

harus diajarkan pertama pada anak di lingkungan keluarga. Anak akan meniru apa yang diajarkan oleh anggota keluarganya bahkan juga melekat di pikirannya, jadi perilaku anak merupakan cerminan dari perilaku keluarganya. Dimana anak mudah memahami dan meniru apa yang selalu dia lihat setiap harinya.

Ketika mendapati suatu masalah ada anak yang menyikapinya dengan marah secara berlebihan yang disebut temper tantrum. Perilaku tersebut sering terjadi pada usia 4-6 tahun, biasanya saat keinginannya tidak terpenuhi anak akan cenderung marah-marah. Anak yang sering mengalami tantrum maka semakin tinggi kecenderungan anak untuk melakukan tantrum kembali, ketika anak melampiaskan energi dan emosi yang terpendam. Kadangkala anak tantrum ketika dibujuk malah ia menjadi-jadi dan terjadi sebaliknya, misal anak lebih menjerit bahkan membanting-banting dirinya. Melihat anak yang tantrum, orang sekitarnya menjadi ikut bingung dan memicu emosinya bahkan juga merasa malu, cemas dan merasa bersalah.

Terjadinya permasalahan dalam kehidupan anak merupakan hambatan yang serius dan memiliki efek jangka panjang untuk keberlangsungan hidupnya. Bimbingan konseling merupakan bagian kegiatan pendidikan/sekolah yang memiliki fungsi membantu anak dalam perkembangannya, membantu anak agar terhindar terjadinya masalah dan mampu membantu menyelesaikan masalah yang ditemuinya. Bimbingan konseling di sekolah sangat membantu permasalahan yang di hadapi oleh anak maupun guru yang kesulitan dalam melaksanakan kegiatan di sekolah. Berdasarkan persoalan diatas, maka penulis akan mengkaji tentang "Bagaimana peran bimbingan konseling dalam mengatasi anak temper tantrum di RA Anak Shaleh Suwayuwo". 


\section{METODE PENELITIAN}

Berdasarkan jenis data yang digunakan dan tujuan penelitian yang akan dicapai, jenis penelitian yang digunakan oleh peneliti adalah penelitian kualitatif. Dengan menggunakan metode deskriptif Metode kualitatif adalah prosedur penelitian yang menghasilkan data deskriptif berupa kata-kata tertulis atau lisan dari orang-orang dan prilaku yang dapat di amati. 6 Penelitian ini juga melengkapi data dengan cara observasi dan wawancara yang di lakukan di RA Anak Shaleh Suwayuwo.

Tujuan penelitian ini bukan hanya untuk mendeskripsikan suatu objek yang diteliti saja. Namun penelitian ini mencakup proses pengeksplorasian fakta dan data objek dilapangan. Peran bimbingan dan konseling dapat mengatasi anak yang tamper tantrum. Pada dasarnya bukan hanya sekedar realitas sosial yang bersifat kontektual, maka tafsiran kualitatif sangat perlu dilakukan agar memberi keyakinan dan dan gambaran secara integratif.

Pengambilan sempel pada awal pengamatan guru kelas merekomendasikan anak yang sesuai dengan kriteria yang akan di teliti dan juga menyetujui anak didiknya menjadi subjek penelitian. Sehingga memudahkan untuk pengamatan berlangsung dalam penelitian. Kriteria yang menjadi sampel dalam penelitian ini adalah Anak dengan usia 4-5 tahun tepatnya anak kelompok A di RA Anak Shaleh Suwayuwo, merupakan anak didik baru, anak yang sering mengalami tamper tantrum.

\section{KERANGKA TEORI}

\section{A. Tinjauan Tentang Peran Bimbingan Konseling}

Peran bimbingan konseling terdiri dari kata peran, bimbingan dan konseling. Peran memiliki arti "pemain sandiwara" yang berarti seseorang

${ }^{6}$ Nurul Khasanah and Tomi Listiawan, "Analisis Berpikir Kritis Siswa Dalam Pemecahan Masalah Matematika Pada Materi Lingkaran" 2, no. 9 (2017): 911-22, https://doi.org/10.31227/osf.io/wsza9. 
Adela Tsamrotul Fikriyah, Imam Syafi'i, Peran Bimbingan Konseling Dalam Mengatasi Anak Temper Tantrum

yang menjadi bagian utama terutama dalam terjadinya suatu peristiwa. ${ }^{7}$ Menurut Soekanto ${ }^{8}$ jika seseorang menjalankan suatu hak dan kewajiban sesuai dengan kedudukannya maka ia menjalankan suatu peranan. Peran dapat dilihat dari bentuk keterlibatan seseorang, kontribusi dan penetapan tujuan.

Bimbingan berasal dari kata bimbing yang memiliki arti tuntunan. Maka bimbingan adalah tuntunan yang diberikan kepada seseorang untuk mengatasi kesusahan yang ada dalam dirinya. Menurut Tolbert 9 bimbingan merupakan semua program kegiatan dan layanan di lembaga pendidikan, yang difokuskan untuk membantu manusia dalam menyelesaikan suatu persoalan serta menyusun suatu rencana".

Konseling disebut juga sebagai pengarahan. Konseling merupakan suatu bimbingan yang diberikan oleh ahli atau konselor kepada seseorang dengan menggunakan metode tertentu. Menurut Gladding konseling adalah suatu ahli atau bidang pekerjaan, yang berarti seseorang yang memiliki bidang pekerjaan dalam memberikan pelayanan pada individu yang mengalami suatu permasalahan yang disebabkan oleh problem pribadi yang tidak dapat diatasinya sendiri. ${ }^{10}$

Adapun 2 tujuan bimbingan dan konseling yang disebutkan oleh Aunur Rohim Faqih ${ }^{11}$ yaitu tujuan khusus dan tujuan umum. Tujuan khusus yaitu membantu individu dalam memahami potensi dirinya, mengatasi masalah pada dirinya, dan membantu memelihara situasi atau kondisi yang baik agar tidak menjadi sumber persoalan dalam dirinya dan

${ }^{7}$ Rafid Rachmatullah, "Peranan Orang Tua Dalam Mengatasi Dampak Negatif

Penggunaan Gadget Pada Anak Di Desa Cikatomas Kecamatan Cilograng Kabupaten Lebak Provinsi Banten,” 2017, 9-29.

8 Suharsono, Fitriyani, And Upoyo, "Hubungan Pola Asuh Orang Tua Terhadap Kemampuan Sosialisasi Pada Anak Prasekolah Di Tk Pertiwi Purwokerto Utara."

9 Indana Khoiroh, "Bimbingan Dan Konseling Islam Dengan Pendekatan Behaviour Dalam Menangani Tantrum Seorang Anak Di Tpq Al-Istiqomah Wedoro Candi Waru Sidoarjo."

$10 \mathrm{lbid}$.

11 lbid. 
orang lain. Sedangkan tujuan um um yaitu membantu dalam mewujudkan potensi dirinya sebagai manusia seutuhnya supaya mendapatkan kebahagiaan hidupnya. ${ }^{12}$

Bentuk peran bimbingan dan konseling mencakup tugas dari konselor sebagai wujud tanggung jawab atas profesi yang dijalankannya. Bimbingan dan konseling memiliki tanggung jawab dalam pelaksanaan program layanan terhadap siswa. Serta melakukan pembinaan dan pengembangan pada siswa sesuai dengan kebutuhannya, potensi, bakat dan minat, dan semua kepribadian siswa di sekolah.

\section{B. Tinjauan Tentang Anak Temper Tantrum}

Tantrum adalah luapan emosi pada anak usia dini seperti menangis dengan nada tinggi, kakinya menendang-nendang, berguling-guling di lantai, hingga melempar-lempar barang disekitarnya ${ }^{13}$. Tantrum biasanya disebabkan oleh keterbatasan kemampuan berbahasa anak untuk mengekspresikan perasaannya, dan juga ada yang disebabkan oleh gangguan perilaku ataupun psikologis anak.

Pada anak usia 4-6 tahun seingkali mengalami temper tantrum. Rini Hildayani, dkk ${ }^{14}$ mengemukakan ada tiga jenis tantrum pada anak, yaitu:

1. Manipulative Tantrum, terjadi karena keinginan anak tidak terpenuhi dan ketika keinginan tersebut dipenuhi anak akan berhenri tantrum.

2. Verbal Frustation Tantrum, terjadi karena tidak tahu bagaimana menyampaikan keinginannya dengan jelas, anak akan berhenti tantrum seiring dengan peningkatan kemampuan komunikasi anak.

12 lbid.

${ }^{13}$ Elieen Heyes, "Tantrum," Erlangga, (2003).

14 Indana Khoiroh, "Bimbingan Dan Konseling Islam Dengan Pendekatan Behaviour Dalam Menangani Tantrum Seorang Anak Di Tpq Al-Istiqomah Wedoro Candi Waru Sidoarjo." 
Adela Tsamrotul Fikriyah, Imam Syafi'i, Peran Bimbingan Konseling Dalam Mengatasi Anak Temper Tantrum

3. Temperamental Tantrum, terjadi tingkat emosi anak tinggi dan tidak bisa terkontrol. Anak sulit untuk mendapatkan kontrol terhadap dirinya sendiri sehingga anak mengalami kondisi mental yang berubah dimana anak tidak mengetahui waktu atau tempat pada saat itu.

\section{TEMUAN DAN PEMBAHASAN}

Proses pendidikan bukanlah proses pengembangan dari segi intelektual saja, melainkan proses pengembangan seluruh segi kepribadian anak, karena pribadi masing-masing anak berbeda-beda. Selain kepribadian dasar anak usia dini memiliki karakter yang berbedabeda juga. Dalam suatu pendidikan bukan proses untuk menyamaratakan perkembangan anak dan karakter yang dimiliki oleh anak, tetapi dalam suatu pendidikan merupakan wadah untuk seseorang mengembangakan potensi maupun totalitas dalam bersosialitas. Pada anak usia 0-6 tahun mengalami proses tumbuh kembang yang sangat unik. Bimbingan konseling untuk anak tidak cukup jika hanya melalui kegiatan pelajaran saja. Akan tetapi kita perlu kegiatan lain yang membuat pertumbuhan dan perkembangan anak semakin meningkat misalnya dengan bermain. Bermain merupakan dunia anak usia dini, dari situ kita dapat memberikan rangsangan bimbingan kepada anak.

Semua anak pasti perlu bimbingan dan selalu memerlukan bantuan. Pada anak usia dini juga perlu diberikan suatu rangsangan agar dapat mengalami perkembangan fundamental bagi kehidupan selanjutnya. Pada anak usia 4-5 tahun dari apa yang saya temukan memerlukan proses untuk menyesuaikan diri dengan lingkungan yang baru. Karena salah satu tugas perkembangan menurut Robert J. Havighurst ${ }^{15}$ adalah belajar kontak perasaan dengan orang tua, keluarga, orang lain, serta menghubungkan diri sendiri secara emosional.

\footnotetext{
${ }^{15}$ Miftahul Jannah, "Tugas-Tugas Perkembangan Pada Usia Kanak-Kanak," Gender

Equality: International Journal of Child and Gender Studies 1, no. 2 (2015): 89-91.
} 134 
Tantrum adalah perilaku agresif anak seperti menangis, berteriak ataupun luapan frustrasi yang tampak hingga hilang kendali pada dirinya. Biasanya ditandai dengan berguling-guling dilantai, memukul-mukul, membuang atau membanting barang disekitarnya, menghentakkan kaki di lantai, membenturkan kepalanya dan berbagai kegiatan lainnya ${ }^{16}$. Kadangkala sampai pipis, batuk, muntah, bahkan ada yang sampai sesak nafas akibat terlalu banyak menangis. Pada dasarnya anak mengalami temper tantrum karena ketidakmampuan anak dalam menontrol emosionalnya sebagai respon dari keinginannya yang belum terpenuhi.

Pada anak usia 4-5 tahun sebaiknya sudah mulai mengolah komunikasinya dalam menyampaikan kebutuhan serta keinginannya. Namun pada kenyataanya di sekolah masih ada beberapa anak yang masih belum bisa megolah komunikasinya dalam menyampaikan kebutuhan serta keinginannya tersebut. Adapun anak ketika sekolah atau saat pembelajaran berlangsung di ruang kelas menunjukkan sikap marah, menangis serta memberontak dikarenakan bingung akan menyampaikan emosinya tersebut. Hal itu terjadi dikarenakan anak belum mampu mengontrol dirinya sendiri serta membutuhkan kasih sayang sehingga anak memiliki hubungan yang hangat dengan orang lain ataau orang disekitarnya. Agar tidak menganggu pembelajaran yang dilaksanakan. Guru menyerahkan kepada layanan bimbingan konseling agar dapat membantu mengatasi permasalahan yang terjadi.

Dari informasi yang diketahui terdapat beberapa hal-hal yang terjadi menurut beberapa ahli psikologi Abraham Maslow ${ }^{17}$, penyebab anak sering mengalami temper tantrum membutuhkan 5 kebutuhan dasar. Kebutuhan dasar tersebut adalah sebagai berikut:

${ }^{16}$ Tandry, "Bad Behavior, Tantrum, and Tampers: Panduan bagi orang tua untuk mengatasi dan memahami perilaku buruk yang sering terjadi pada balita 2-4 tahun," Jakarta: Gramedia, (2010).

17 Nenden Ineu Herawati, "Menghadapi Anak Usia Dini Yang Temper Tantrum," N.D. 
Adela Tsamrotul Fikriyah, Imam Syafi'i, Peran Bimbingan Konseling Dalam Mengatasi Anak Temper Tantrum

1. Kebutuhan pertama yaitu kebutuhan fisiologis. Seperti rasa haus, lapar, membutuhkan pakaian, dan lain sebagainya.

2. Kebutuhan kedua yaitu kebutuhan akan rasa keslamatan, kenyamanan, proteksi, serta bebas akan rasa takut.

3. Kebutuhan ketiga yaitu kebutuhan kasih sayang serta memiliki hubungan yang hangat dengan orang lain agar anak merasa bahwa dirinya adalah bagian dari kelompok.

4. Kebutuhan keempat yaitu kebutuhan dihargai serta dihormati oleh orang lain.

5. Kebutuhan kelima yaitu kebutuhan keinginan dirinya individu akan mengembangkan dirinya ketika kebutuhan satu sampai dengan 4 sudah terpenuhi.

Berdasarkan pendapat para ahli tentang konsep bimbingan dan konseling pada anak usia dini dapat di artikan sebagai upaya bantuan yang dilakukan guru/pendamping terhadap anak usia dini agar anak dapat tumbuh dan berkembang secara optimal serta mampu mengatasi permasalahan-permasalahan yang akan di hadapinya. Adapun secara khusus layanan bimbingan konseling pada anak usia dini dilakukan untuk membantu mereka untuk dapat :

1. Lebih mengenal dirinya, kemampuannya, sifatnya, kebiasaanya dan kesenangannya.

2. Mengembangkan potensi yang dimilikinya

3. Mengatasi kesulitan-kesulitan yang sedang dihadapinya

4. Menyiapkan perkembangan mental dan sosial anak untuk masuk ke lembaga pendidikan selanjutnya.

Di lihat dari tujuannya, salah satu lingkup layanan bimbingan untuk anak usia dini mengutamakan penekanan pada jenis kegiatan, yaitu 
bimbingan pribadi sosial. Bimbingan ini di maksud untuk mencapai tujuan dan tugas perkembangan pribadi sosial anak dalam mewujudkan pribadi yang mampu menyesuaikn diri dan bersosialisasi dengan lingkungan secara baik. Bimbingan pribadi-sosial merupakan bimbingan untuk membantu anak dalam memecahkan masalah-masalah pribadi-sosial.

Bersadarkan hasil observasi, dan wawancara terhadap guru di RA Anak Shaleh peneliti mendapatkan informasi mengenai latar belakang anak mengalami temper tantrum. Berikut ciri-ciri anak tantrum pada kelompok A di RA Anak Shaleh:

1. Berteriak serta menangis.

Kondisi tersebut diluapkan anak karena suatu permintaan atau keinginan mereka yang tidak terpenuhi. Menurut guru di Ra Anak Shaleh perilaku anak tersebut masih bisa diatasi dengan cara dibujuk dan dialihkan perhatiannya dari apa yang diinginkan anak tersebut.

2. Menangis, membanting dirinya, melempar barang disekitarnya serta perilaku yang membahayakan lainnya.

Kondisi tersebut biasanya muncul ketika anak merasa dirinya terganggu dan juga tidak bisa mengungkapkan apa yang dirasakan. Berdasarkan observasi yang telah dilakukan, guru terlihat kuwalahan dengan perilaku anak tersebut. Hal yang bisa dilakukan guru dalam mengatasi perilaku tersebut dengan cara mendiamkan anak atau memberi waktu sebentar pada anak, mengambil barang-barang berbahaya disekitar anak agar tidak dilempar-lempar lagi. Setelah itu, memuji anak tersebut agar sedikit berkurang tantrumnya, tetapi hal tersebut tidak jarang anak yang bisa terkendali dengan upaya yang dilakukan oleh guru. Pada intinya ketika anak mengalami temper tantrum jangan sesekali memberikan hukuman serta memarahi anak karena pada dasarnya temper tantrum tersebut malah semakin menjadi-jadi. 
Adela Tsamrotul Fikriyah, Imam Syafi'i, Peran Bimbingan Konseling Dalam Mengatasi Anak Temper Tantrum

Dalam melakukan bimbingan konseling di RA Anak Shaleh Suwayuwo agar berjalan dengan baik sebelum memberikan layananlayanan bimbingan konseling kepada anak, konselor menyusun langkahlangkah yang harus dilakukan agar terinci dan maksimal dalam melakukan penanganan. Langkah-langkah bimbingan konseling dalam mengatasi anak yang mengalami temper tantrum adalah:

1. Bersikap tenang, tarik nafas dan mencoba menenangkan diri saat menghadapi perilaku temper tantrum anak pada saat itu.

2. Kenali dan cari penyebab anak tamper tantrum, identifikasi masalah apa yang sedang dirasakan anak dengan menanyakan sesuatu pada anak tersebut. Misalnya "apakah ada kata-kata ibu guru tadi yang membuat kamu marah dan tidak enak hati ?" contoh lain "Apakah ada sesuatu yang kamu inginkan? “

3. Buat anak mengatakan kebutuhan ataupun keingiannya, bantulah anak mengolah komunikasi untuk menyatakan apa yang diinginkan sertayang tidak diinginkan anak. besar harapan agar kita dapat memahami, mengerti perasaan dan keinginannya.

4. Beri alternatif atau pilihan lain, misalkan ibu guru tidak menginginkan jika kamu sekolahnya masih ditungguin, karena kalu disekolah kita belajarnya sama ibu guru bukan sama mama. Lihat! banyak temanteman yang mau belajar dan bermain sama kamu. Berilah kegiatan main yang menarik dan menyenangkan agar anak lupa akan perasaannya.

5. Beri pelukan kasih sayang, coba berikan pelukan dengan penuh kasih sayang agar anak dapat menurunkan emosinya dan tidak bertindak agresif seperti berguling-guling di lantai, menghentak-hentakkan kakinya dan lain sebagainya. 
Jika tantrum mulai mereda usahakan kita tetap konsisten. jika temper tantrum muncul akibat tidak terpenuhinya keinginan anak, usahakan keinginan tersebut tetap tidak diberikan. Akan tetapi anak diberi penjelasan mengapa keinginannya tersebut tidak dapat terpenuhi. dan berikan pengertian bahwa perilaku temper tantrum tersebut tidak baik untuk dilakukan.

\section{KESIMPULAN}

Ketika anak mengalami temper tantrum jangan sesekali memberikan hukuman serta memarahi anak karena pada dasarnya temper tantrum tersebut malah semakin menjadi-jadi. Akan tetapi berilah perlakuan yang hangat, nyaman dan menyenangkan, serta ajak anak untuk mengolah komunikasi dalam penyampaian kebutuhan dan keinginannya. Dan apabila keinginan tersebut tidak bisa terpenuhi maka berikan pilihan lain yang lebih menarik untuknya.

Terdapat dua ciri anak mengalami tantrum di RA Anak Shaleh Suwayuwo diantaranya yaitu anak menangis serta berteriak, dan anak menangis dan melakukan hal yang membahayakan seperti melepar barang-barang. Layanan bimbingan konseling dalam mengatasi anak yang temper tantrum di RA Anak Shaleh Suwayuwo dengan cara bersikap tenang, mengidentifikasi permasalahan anak, mengalihkan perhatian anak, serta memberika pelukan kasih sayang anak. Dengan cara tersebut anak yang sering mengalami temper tantrum dapat diatasi.

\section{DAFTAR PUSTAKA}

Herawati, Nenden Ineu. 2012. "Menghadapi Anak Usia Dini yang Temper Tantrum." Jurnal Pendidikan Anak Usia Dini Cakrawala Dini Volume 3 No. 2.

Heyes, Elieen. 2003. Tantrum. Jakarta: Erlangga. 
Adela Tsamrotul Fikriyah, Imam Syafi'i, Peran Bimbingan Konseling Dalam Mengatasi Anak Temper Tantrum

Jannah, Miftahul. 2015. "Tugas-Tugas Perkembangan Pada Usia KanakKanak ." Gender Equality: International Journal of Child and Gender Studies 1, No. 2 89-91.

Joko Tri Suharsono, Aris Fitriyani dan Arif Setyo Upoyo. 2009. "Hubungan Pola Asuh Orang Tua Terhadap Kemampuan Sosialisasi Pada Anak Prasekolah di TK Pertiwi Purwokerto Utara." Jurnal Keperawatan Soedirman 4 No. 3112-118.

Kamaluddin, H. 2011. "Bimbingan dan Konseling Sekolah." Jurnal Pendidikan dan Kebudayaan 17, No. 4447.

Khoiroh, Indana. 2014. Bimbingan dan Konseling Islam Dengan Pendekatan Behaviour Dalam Menangani Tantrum Seorang Anak di TPQ Al-Istiqomah Wedoro Waru Sidoarjo. Surabaya: Skripsi Universitas Islam Negeri Sunan Ampel Surabaya.

Listiawan, Nurul Khasanah dan Tomi. 2017. "Analisis Berpikir Kritis Siswa dalam Pemecahan Masalah Matematika pada Materi Lingkaran." Seminar Nasional Hasil Penelitian dan Abdimas STKIP PGRI Pacitan. Pacitan: STKIP PGRI Pacitan. 291-299.

Rahmatullah, Rafid. 2017. Peranan Orang Tua dalam Mengatasi Dampak Negatif Penggunaan Gadget pada Anak di Desa Cikatomas Kecamatan Cilograng Kabupaten Lebah Provinsi Banten. Bandung: Universitas Pasundan.

Suryana, Dadang. 2018. "Teori dan Praktek Pembelajaran." International Journal of Physiology 6 No. 1.

Susiana. 2019. "Pelaksanaan Bimbingan dan Konseling Bagi Anak Jalanan di Padepokan Anggur ljo Ngaliyan Semarang." Walisongo Repository.

Tandry. 2010. Bad Behaviour, Tantrum and Tampers: Panduan Bagi Orang Tua untuk Mengatasi dan Memahami Perilaku Buruk yang Sering Terjadi Pada Balita 2-4 Tahun. Jakarta: Gramedia. 